\title{
Vitreoretinal reactions and persistent hyaloid vessels
}

\author{
FRITZ H. STEFANI AND W. ANNA LASZCZYK* \\ From the University Eye Hospital, Munich
}

In the large series of cases of pseudoglioma reported by Howard and Ellsworth (1965) the conditions of persistent hyaloid vessels (PHV) or persistent primary vitreous (PPV) often occurred as a single anomaly, but only rarely as part of a syndromefor example, Reese's dysplasia, Heine-Norrie's disease, incontinentia pigmenti Bloch-Sulzberger, Laurence-Moon-Bardet-Biedl's syndrome, chromosomal anomalies of group D.

Retinal changes may be combined with PHV and PPV - that is, with retinal folds (Mackensen, 1953), falciform retinal detachment (v. Barsewisch, 1968), areas of chorioretinal atrophy (Gloor, 1975), or atypical retinal detachment (Gloor and Haller, 1968). Retinal dysplasia is a lesion more often found in association with complex anomalies; Ricci (1969) used the term vitreoretinal dysplasia for such cases.

Vitreoretinal adhesions (Mann, 1935) have been shown experimentally to occur as a developmental anomaly (Orts Llorca and Genis Gálvez, 1960). Tripathi and Ashton (197I) found that vaso-glial connexions were normal in the adult rabbit. Vitreoretinal strands in man are regarded as being degenerated vitreoretinal anastomoses of blood vessels (Hagedoorn and Sieger, 1956; Reese, 1955; Wolter and Flaherty, 1959; Spaulding and Naumann, 1967; Gärtner, 1964). These strands are also seen in cases of non-oxygen induced retinitis proliferans in full-term infants (Stefani and Ehalt, 1974). The observation that retinitis proliferans occurs with other anomalies (Krümmel and Rausch, 1955; Benedikt and Ehalt, 1970; Addison, Font, and Manschot, 1972; Stefani and Ehalt, 1974; Best and Rentsch, 1974) is of importance regarding the mechanism of lesions that histologically mimic retrolental fibroplasia but which occur in children who have not received oxygen treatment, and of possible significance in understanding the mechanism that leads to fibroplasia.

We have records of only eight cases of PPV, relatively few compared with other hospitals (Manschot, 1958; Font, Yanoff, and Zimmerman, 1969; Jensen, 1968), but these are sufficient to

Supported by a grant from the Alexander von Humboldt-Stiftung

Address for reprints: Dr F. Stefani, Augenklinik der Universität München, 8 München 15, Mathildenstrasse 8, W. Germany advance some views of vitreoretinal reactions induced by persistent vascularized tissue within the eye; in cases which mimic retrolental fibroplasia the blood vessel formation was of especial interest.

\section{Material}

Each of the eight cases had been full-term and only one infant (Case 4) had received oxygen treatment because of cyanosis (Table I). The particulars of the clinical and macroscopical findings are given in Table II. Case 4 was clinically suggestive of $13^{-1} 5$ trisomy. The diagnosis of PPV was not made clinically.

\section{histological findings (Table III)}

\section{Persistent primary vitreous ( $P P V$ )}

The appearance of PPV varied considerably from loose cellular forms similar to normal (embryonic) primary vitreous (Cases I, 2, and 3) to firm fibrous or scarlike forms (Cases 4, 5, 6, and 8). One (Case 7) showed a fatty transformation and another (Case 4) contained nests of chondroid tissue. The cellular form contained mainly two cell types, of fibroblastic and macrophagic vitreo-cystoid elements arranged in a netlike pattern. In a few sections in Case $\mathrm{I}$, a large intracellular periodic acid-Schiff-positive globule resembling a corpus amylaceum could be seen, but it was not possible to classify the surrounding cell. This cellular form of PPV was usually well vascularized while the fibrous form showed only poor vascularization, as did the form showing fatty degeneration.

\section{Persistent hyaloid vessels (PHV)}

Not all cases showed an obvious or patent persistent hyaloid artery (PHA) or vasa hyaloidea propria. Signs of obliteration of the PHA (thickening of the tunica intima and delamination of the internal elastic membrane with narrowing of the lumen) were not seen. The hyaloid blood vessel system was particularly prominent in Cases I to 3. Patent anastomosing vitreoretinal blood vessels were present in Cases I, 2, 4, and 8 (Fig. I). There were some glial cells sheathing the preretinal portion of the blood vessel anastomoses and prominent vitreoretinal strands were usually observed near by in these cases. These vitreoretinal strands consisted of a cellular (glial) portion on the retinal side which became fibrillary towards the vitreous. In some there were signs of traction along the strands with formation of retinal folds 
Table I General clinical findings in eight cases

\begin{tabular}{|c|c|c|c|c|c|c|c|}
\hline $\begin{array}{l}\text { Case } \\
\text { (no.) }\end{array}$ & Sex & Age & $\mathrm{O}_{2}$ & Other eye & $\begin{array}{l}\text { Other clinical } \\
\text { malformations }\end{array}$ & Other clinical findings & Cause of enucleation \\
\hline $\mathbf{r}$ & Boy & I month & - & Normal & 一 & 一 & Hydrophthalmus \\
\hline 2 & Girl & 3 months & - & Normal & 一 & $\begin{array}{l}\text { Grandmother } 47 \text { years old, myopic; } \\
\text { mother } 22 \text { years old, myopic } \\
\text { with peripheral retinal degenera- } \\
\text { tion, holes and marked pupillary } \\
\text { membrane; aunt } 23 \text { years old, } \\
\text { myopic; uncle } 14 \text { years old, myopic } \\
\text { with peripheral retinal degenera- } \\
\text { tion and retinal holes }\end{array}$ & $\begin{array}{l}\text { Suspected retinoblastoma } \\
\end{array}$ \\
\hline 3 & Boy & 4 months & - & Normal & $\longrightarrow$ & - & Suspected retinoblastoma \\
\hline 4 & Girl & I month & + & $\begin{array}{l}\text { Cryptophthal- } \\
\text { mus }\end{array}$ & $\begin{array}{l}\text { Cardioversion, hypoplasia } \\
\text { of the lungs intestinal } \\
\text { abnormalities }\end{array}$ & Cyanosis, death due to pneumonia & Necropsy \\
\hline 5 & Boy & 13 years & - & Normal & - & 一 & Secondary glaucoma \\
\hline 6 & Boy & 6 months & - & Normal & 一 & Maternal bleeding at 4 to 6 months & Suspected retinoblastoma \\
\hline 7 & Boy & 4 years & - & Normal & 一 & 一 & Hydrophthalmus \\
\hline 8 & Boy & 5 years & - & Normal & 一 & 一 & Suspected intraocular tumour \\
\hline
\end{tabular}

Table II Clinical and macroscopical findings in enucleated eyes

\begin{tabular}{|c|c|c|}
\hline $\begin{array}{l}\text { Case } \\
\text { (no.) }\end{array}$ & Clinical findings & Macroscopical findings \\
\hline $\mathbf{I}$ & $\begin{array}{l}\text { Hydrophthalmus } \\
\text { Corneal clouding } \\
\text { Cataractous lens }\end{array}$ & $\begin{array}{l}\text { Large globe } \\
\text { Intracorneal filtering bleb (due to } \\
\text { partial absence of Descemet's } \\
\text { membrane) } \\
\text { Small cataractous lens with } \\
\text { calcification } \\
\text { PHV and PPV } \\
\text { Tunica vasculosa lentis }\end{array}$ \\
\hline 2 & $\begin{array}{l}\text { Microphthalmus } \\
\text { Cataractous lens }\end{array}$ & $\begin{array}{l}\text { Small globe } \\
\text { Cataract, posterior lenticonus } \\
\text { Total retinal detachment }\end{array}$ \\
\hline 3 & Leucocoria & $\begin{array}{l}\text { Total retinal detachment } \\
\text { Iridocorneal adhesions } \\
\text { Pre- and intraretinal haemorrhages }\end{array}$ \\
\hline 4 & $\begin{array}{l}\text { Suspected crypt- } \\
\text { ophthalmus or } \\
\text { anophthalmus }\end{array}$ & $\begin{array}{l}\text { Cryptophthalmus, marked micr- } \\
\text { ophthalmus } \\
\text { Sclerocornea } \\
\text { Obliterated anterior chamber } \\
\text { Small cataractous lens with } \\
\text { calcification } \\
\text { Connective tissue with chondroidal } \\
\text { deposits in front of the folded } \\
\text { nasal retina }\end{array}$ \\
\hline 5 & $\begin{array}{l}\text { Cataractous lens } \\
\text { since birth } \\
\text { Glaucoma } \\
\text { Hyphaema }\end{array}$ & $\begin{array}{l}\text { Cataractous, partly calcified lens, } \\
\text { falciform retinal detachment } \\
\text { nasally with adhesion to the lens }\end{array}$ \\
\hline 6 & $\begin{array}{l}\text { Microphthalmus } \\
\text { Sclerocornea } \\
\text { Leucocoria }\end{array}$ & $\begin{array}{l}\text { Small globe } \\
\text { Aphakia } \\
\text { Suspected ciliary and optic coloboma } \\
\text { Retinal detachment }\end{array}$ \\
\hline 7 & $\begin{array}{l}\text { Hydrophthalmus } \\
\text { Leucocoria }\end{array}$ & $\begin{array}{l}\text { Large globe } \\
\text { Fatty tissue in the posterior chamber } \\
\text { area (PPV?) }\end{array}$ \\
\hline 8 & $\begin{array}{l}\text { Microphthalmus } \\
\text { Choroidal coloboma } \\
\text { Cataract }\end{array}$ & $\begin{array}{l}\text { Small globe } \\
\text { Choroidal coloboma } \\
\text { Cataractous lens } \\
\text { PPV } \\
\text { Total retinal detachment }\end{array}$ \\
\hline
\end{tabular}

(Fig. 2). Sometimes there was a close spatial relationship of PHV to the retina (Fig. 3) which was avascular in these areas. In three (Cases 2, 3, and 8) there was new vessel formation on the surface of an avascular retinal area (Fig. 4); there were no intraretinal glomeruloid endothelial proliferations suggestive of proliferation of retinal vessels but there were connexions to the vasa hyaloidea propria.

\section{Retinal vascular changes}

The avascular retinal areas were present mainly in the temporal periphery (Cases I to 4 , and 8), although there was an avascular retinal area on the nasal side in some cases. In two cases, the vascular system was hypoplastic-for example, smaller blood vessels with wide intercapillary spaces. In the case of falciform retinal detachment there was a marked fibrosis of blood vessels in the area of attachment. In only one case did the retinal vascular system appear normal. In three eyes with peripheral temporal avascular retina, there were the already described new vessel formations on the retinal surface of these areas.

\section{Structural retinal changes}

Changes of the retinal structure were mainly due to loss or rarefaction of ganglion cells or microcystoid degeneration. Other changes present were various degrees of gliosis, retinal dysplasia, or cystic retinoschisis. Retinal fold formations by contracted vitreoretinal strands have already been mentioned.

\section{Associated ocular changes}

There were other changes associated with these cases of PPV - for example, hypoplasia of the anterior segment, cataracts and colobomata-but these are mentioned here only for the sake of completing the histological findings. 
Table III Histology of vitreoretinal changes in eight cases

\begin{tabular}{|c|c|c|c|c|c|c|}
\hline $\begin{array}{l}\text { Case } \\
\text { (no.) }\end{array}$ & $P H V$ & $P P V$ & $\begin{array}{l}\text { Vitreoretinal } \\
\text { anastomoses of } \\
\text { blood vessels }\end{array}$ & $\begin{array}{l}\text { Proliferating } \\
\text { preretinal blood } \\
\text { vessels }\end{array}$ & Retinal vascular changes & Changes in retinal structure \\
\hline $\mathbf{I}$ & ( & $\begin{array}{l}+ \\
\text { (Anterior and } \\
\text { posterior) }\end{array}$ & + & - & $\begin{array}{l}\text { Peripheral temporal retina } \\
\text { with avascular areas }\end{array}$ & $\begin{array}{l}\text { Rarefaction of ganglion cell layer } \\
\text { Microcystoid degeneration at } \\
\text { the posterior pole }\end{array}$ \\
\hline 2 & + & $\begin{array}{l}+ \\
\text { (Anterior and } \\
\text { posterior) }\end{array}$ & + & + & $\begin{array}{l}\text { Peripheral nasal and } \\
\text { temporal retina with } \\
\text { avascular areas }\end{array}$ & $\begin{array}{l}\text { Retinal folds } \\
\text { Microcystoid degeneration } \\
\text { Ganglion cell layer rarefaction } \\
\text { Gliosis }\end{array}$ \\
\hline 3 & + & $\begin{array}{l}+ \\
\text { (Anterior and } \\
\text { posterior) }\end{array}$ & $?$ & + & $\begin{array}{l}\text { Peripheral nasal and } \\
\text { temporal retina with } \\
\text { avascular areas }\end{array}$ & $\begin{array}{l}\text { Intraretinal haemorrhages } \\
\text { Microcystoid degeneration } \\
\text { Loss of ganglion cells } \\
\text { Gliosis }\end{array}$ \\
\hline 4 & $\begin{array}{l}\text { (No obvious } \\
\text { persistent } \\
\text { hyaloid artery) }\end{array}$ & $\begin{array}{l}+ \\
\text { (With chondroidal } \\
\text { changes) }\end{array}$ & $\div$ & - & $\begin{array}{l}\text { Peripheral temporal retina } \\
\text { with avascular area }\end{array}$ & $\begin{array}{l}\text { Nasal retina: loss of the inner } \\
\text { layers, outer layers intact; } \\
\text { dysplastic areas } \\
\text { Temporal retina: loss of ganglion } \\
\text { cells, microcystoid } \\
\text { degeneration }\end{array}$ \\
\hline 5 & $\stackrel{+}{\text { (Not patent) }}$ & + & $\begin{array}{l}- \\
\text { (Except for } \\
\quad \text { adhesion of PHV }\end{array}$ & - & $\begin{array}{l}\text { Temporal retina: hypo- } \\
\text { plastic vascularization } \\
\text { Nasal retina: fibrosis of } \\
\text { blood vessels }\end{array}$ & $\begin{array}{l}\text { Nasal retina: cystic } \\
\text { retinoschisis }\end{array}$ \\
\hline 6 & - & + & - & - & $\begin{array}{l}\text { Hypoplastic retinal blood } \\
\text { vessels }\end{array}$ & $\begin{array}{l}\text { Retinal folds } \\
\text { Rarefaction of inner layers }\end{array}$ \\
\hline 7 & Not obvious & $\begin{array}{l}+ \\
\text { (With fatty } \\
\text { degeneration }\end{array}$ & $\overline{\text { Vitreoretinal strands }}$ & - & 一 & $\begin{array}{l}\text { Loss of inner layers } \\
\text { Some microcystoid degeneration }\end{array}$ \\
\hline 8 & + & + & + & + & $\begin{array}{l}\text { Peripheral temporal retina } \\
\text { with avascular area }\end{array}$ & $\begin{array}{l}\text { Loss of ganglion cells } \\
\text { Marked gliosis }\end{array}$ \\
\hline
\end{tabular}

\section{Discussion}

During normal development, the hyaloid vascular system precedes retinal vascularization and undergoes involution at the seventh month. A persistent vascular system with surrounding connective tissue in the vitreous cavity is likely to be a potential factor in the induction of reactive developmental changes in other intraocular structures.

Vascular vitreoretinal anastomoses and vitreoretinal strands (Reese and Straatsma, 1958; Manschot, 1958; Wolter and Flaherty, 1959; Gärtner, 1964; Spaulding and Naumann, 1967) may be regarded as reactive tissue changes caused by disturbed involution of the primary hyaloid system.

Avascular retinal areas have previously been observed in incontinentia pigmenti or the BlochSulzberger syndrome (Best and Rentsch, I974). Our observation of peripheral avascular retinal areas in eyes of infants between the ages of one month and four years born at full-term is in contrast with that of Reese and Blodi (1949) and Reese (1955) who described a fully developed retina in PPV. The persistence of an avascular retina shows there is no need for retinal vascularization and suggests there is an adequate oxygen supply to this area of retina from the choroidal or vitreous aspects; in our cases this may be due to an increased oxygen level on the vitreous side with its abnormal vascular system (although there is also the possibility of early degenerative retinal changes and a consequent decreased oxygen demand). The same applies to a hypoplastic vascular system. The degree and morphological expression of the various factors involved (Table IV) in the abnormally developing eye may vary widely, and the lack of knowledge of the early stages of PPV would make further statements purely speculative. But with regard to vascularization of the developing intraocular tissues, especially in malformed eyes, we would expect reactions as long as involution, degeneration, and tissue growth have not reached a final stage in which the blood vessel system covers the oxygen need of the tissues sufficiently. Massive new vessel formation is a response to hypoxia which is not necessarily permanent.

According to Foos and Kopelew (1973) the retinal vascular system is complete in only ro per cent of full-term infants. We still see oxygen-induced retrolental fibroplasia although mainly in prematurity and rarely is there an equivalent in fullterm infants; thus an incomplete retinal vascularization at birth does not necessarily imply retinal 


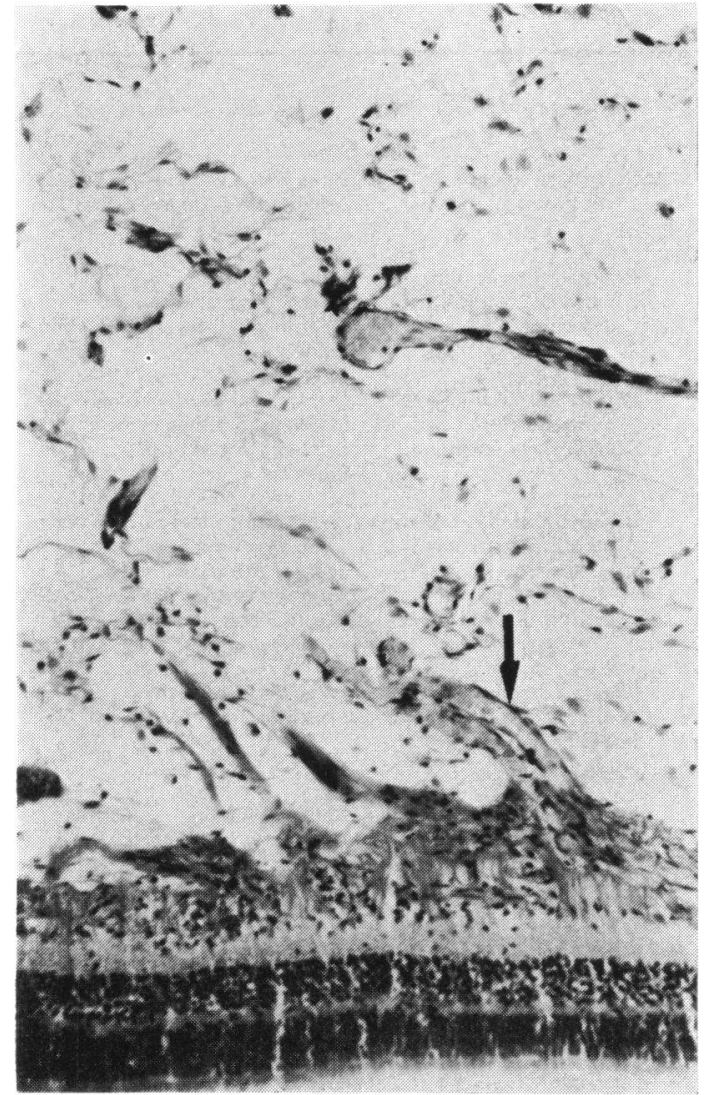

FIG. I Case I. Nasal retina showing vitreoretinal anastomssis of blood vessels (arrow) and vitreoretinal strands. Haematoxylin and eosin. $\times 14 \mathrm{C}$
Table IV Possible factors inducing developmental or reactive vitreoretinal changes

Persistent primary vitreous (PPV) tissues

Involution

Haemodynamics

Hypoxia

Degeneration

Reactive growth

Retinal tissues

ischaemia and with it the risk of retrolental fibroplasia. The persistence of intravitreal blood vessels, however, raises the question whether these vessels may proliferate under certain conditions and thus mimic the proliferative phase of retrolental fibroplasia. Indeed, Gyllensten and Hellström (1954, 1955), Patz (1965), and Ashton (1968) showed in animal experiments that oxygen could induce a proliferation of persistent hyaloid vessels. We noticed formations of new vessels on the surface of peripheral avascular retinal areas that had connexions with the hyaloid system and the absence of intraretinal endothelial proliferation indicates a hyaloid origin. Krümmel and Rausch (1955) and Benedikt and Ehalt (1970) have suggested that the formations of new vessels in incontinentia pigmenti are supplied from the hyaloid artery, while Best and Rentsch (1974) in their case suggested that they were supplied by the retina. So it appears possible that both vascular systems may play a role in the formation of new vessels and ischaemic retinal areas may play a pathogenetic role. This seems of importance in some hitherto unexplained cases of

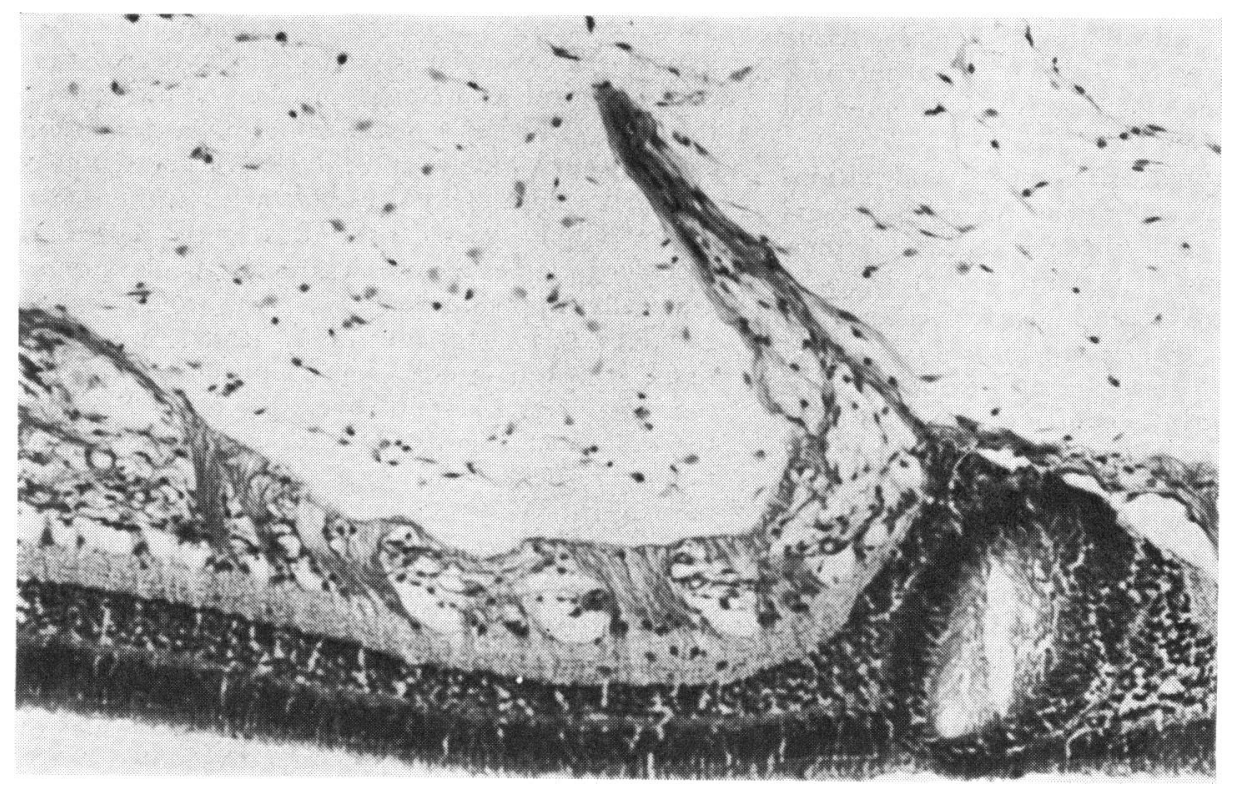

FIG. 2 Case I. Temporal retina with a vitreoretinal strand and formation of a retinal fold in the area of traction. Note also the ischaemic changes in. the inner retina. Haematoxylin and eosin. $\times 140$ 


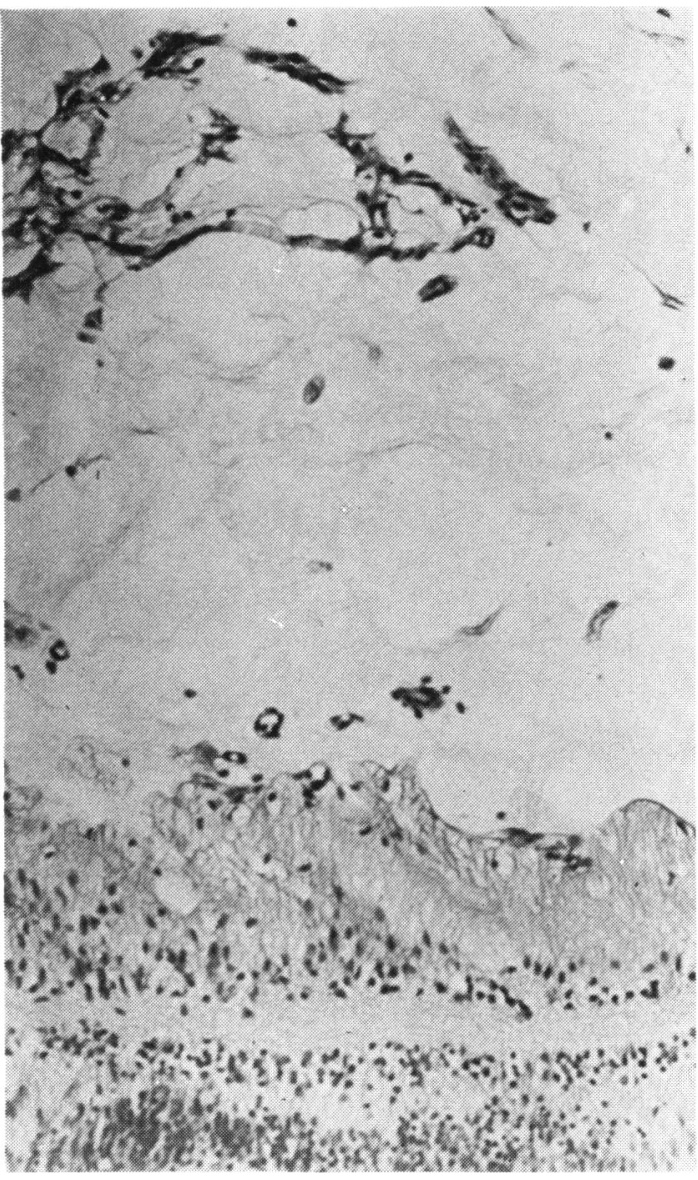

FIG. 3 Case 2. Close spatial relationship of persistent hyaloid blood vessels to the avascular retina. Haematoxylin and eosin. $\times 140$

non-oxygen induced retinitis proliferans in fullterm infants.

That ischaemic changes take place is further shown by the finding of microcystic retinal degenerations and the loss of ganglion cells, although changes of intraocular pressure must also be taken into account.

\section{Summary}

In cases with persistent primary vitreous in fullterm infants there were vitreoretinal reactions in- cluding vitreoretinal anastomoses of blood vessels, vitreoretinal strands, traction folds of the retina, avascular retinal areas, hypoplasia of retinal blood vessels, rarefaction of retinal ganglion cells, and ischaemic structural changes of the retina. New vessel formation on the surface of avascular retinal areas was supplied from persistent hyaloid blood vessels. This finding may be of some importance in explaining those cases histologically resembling classical retrolental fibroplasia with no history of prematurity or oxygen treatment.

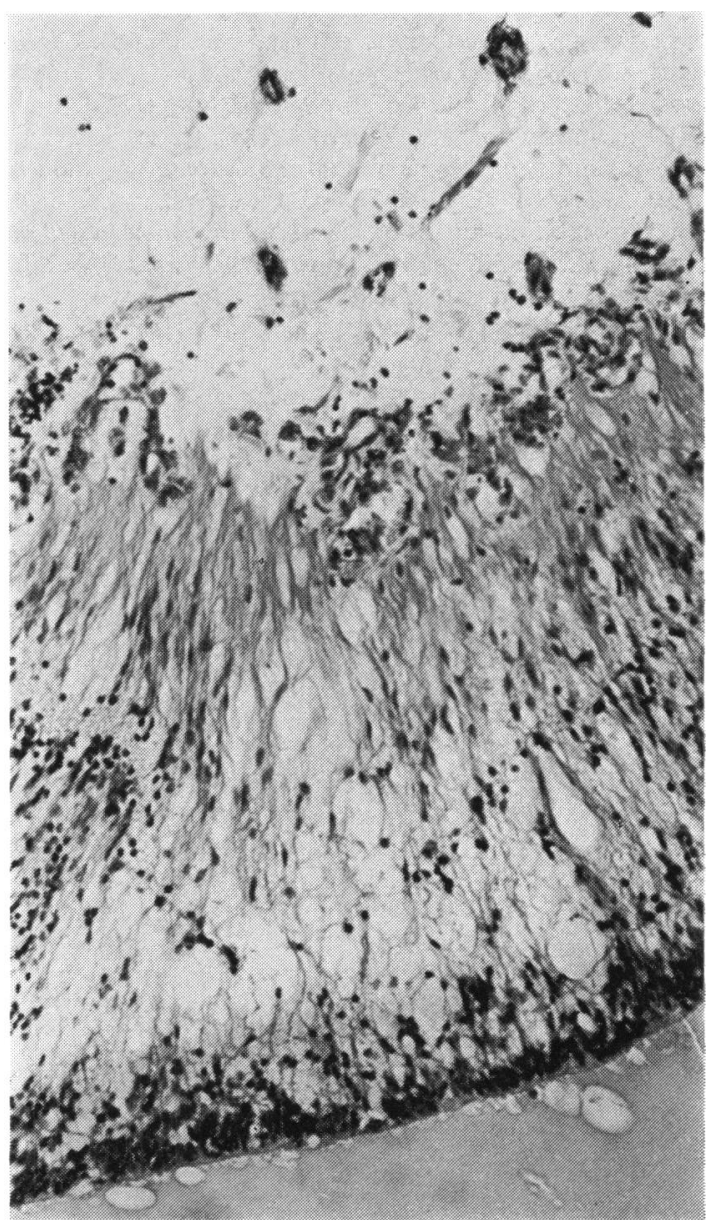

FIG. 4 Case 2. Neovascularization on the avascular retinal surface. Retina shows marked ischaemic changes. Haematoxylin and eosin. $\times 140$

\section{References}

ADDISON, D. J., FONT, R. L., and MANSChOT, w. A. (1972) Amer. F. Ophthal., 74, 697

ASHTON, N. (I 968) Brit. F. Ophthal., 52, 505

BARSEWISCH, vON B. (I968) Ber. dtsch. ophthal. Ges., 68, 48 I

BENEDIKT, o., and Ehalt, H. (1970) Klin. Mbl. Augenheilk., 157, 652

BEST, W., and RENTSCH, F. (1974) Ibid., I64, I9 
FONT, R. L., YANOFF, M., and ZIMMERMan, L. E. (1969) Arch. Ophthal., 82, 43 FOOS, R. Y., and KOPELEW, S. M. (1973) Surv. Ophthal., 18, I 17 GäRTNER, J. (1964) v. Graefes Arch. Ophthal., 167, 103 GLOOR, B. P. (1975) Klin. Mbl. Augenheilk., 166, 293 -, and HALLER, R. (1968) v. Graefes Arch. Ophthal., 175, 193 GYLlENSTEN, L. J., and HeLlSTRÖM, B. E. (1954) Acta paediat. (Uppsala), 43 (suppl. I00), I 3 I $\longrightarrow$, and (1955) Amer. F. Ophthal., 39, 475

HAGEDOORN, A., and SIEGER, D. H. (I956) Ibid., 49, 660

HOWARD, G. H., and ELLSWORTH, R. M. (1965) Ibid., 60, 610

JENSEN, O. A. (1968) Acta ophthal. (Kbh), 46, 418

KRÜMMEL, H., and RAUSCH, L. (1955) Ophthalmologica (Basel), 130, 31

maCkensen, G. (1953) Klin. Mbl. Augenheilk., 123, 4I

MANN, I. (1935) Brit. f. Ophthal., 19, 64I

MANSChOT, W. A. (1958) Arch. Ophthal., 59, 188

ORTS LlORCA, F., and GENIS GÁlVEZ, J. M. (1960) Arch. Soc. oftal hisp.-amer., 20, 9I

PATZ, A. (1965) Invest. Ophthal., 4, 988

REESE, A. B. (1955) Amer. F. Ophthal., 40, 317 , and BLODI, F. C. (1949) Ibid., 33, 23

-

RICCI, A. (1969) F. Génét. hum., I7, suppl. I

SPaulding, A. G., and NaumanN, G. (1967) Arch. Ophthal., 77, 666

STEFANI, F. H., and EHALT, H. (1974) Brit. F. Ophthal., 58, 490

TRIPATHI, B., and ASHTON, N. (197I) Ibid., 55, I

WOlter, J. R., and flaherty, N. (1959) Amer. F. Ophthal., 47, 49 I 